\title{
Laporan Kasus: Pria 60 tahun dengan Eritroderma et causa Dermatitis Seboroik
}

\author{
Dyah R. Anggarini, ${ }^{1 *}$ Sarah D. Pasaribu ${ }^{2}$ \\ ${ }^{1}$ RSUD Dr. Wahidin Sudiro Husodo Kota Mojokerto Jawa Timur \\ ${ }^{2}$ Klinik Kasih Medica Medan Sumatera Utara
}

\begin{abstract}
Abstrak
Eritroderma merupakan peradangan kulit mengenai 90\% atau lebih permukaan kulit biasanya disertai skuama. Pasien laki-laki berusia 60 tahun datang ke RSUD Dr. Wahidin Sudiro Husodo dengan keluhan muncul bercak merah disertai rasa gatal dan kulit mengelupas di seluruh tubuh sejak 1 hari yang lalu. Gatal lebih dirasakan saat berkeringat. Dijumpai sisik berwarna putih teraba kasar di bagian wajah dan sisik kekuningan di bagian kepala. Diketahui ada riwayat alergi pemakaian antibiotik dan analgesik pasca operasi. Pasien juga memiliki riwayat rawat inap berulang lebih dari 5 kali dengan keluhan yang sama, dilakukan biopsi kulit terhadap pasien. Tujuan biopsi untuk mengetahui penyebab eritroderma, mencegah kekambuhan dan memberikan tatalaksana yang tepat bagi pasien. Hasil biopsi kulit ditemukan sel parakeratosis dan sel spongiosis, namun tidak ditemukan sel-sel ganas.
\end{abstract}

Kata Kunci: Eritroderma, Alergi Obat, Biopsi Kulit

\section{Case Report: A 60 years old man with Erythroderma ec. Seborrhoic Dermatitis}

\begin{abstract}
Erythroderma is a skin inflammation that affects $90 \%$ or more on the surface of the skin, usually accompanied by scaly. A 60-years-old male patient came to Wahidin Sudiro Husodo General Hospital with complaints red patches itchy and flaking skin all over the body since 1 day ago. Itching is more felt when sweating. Found rough scaly patches of erythema all over the faces and yellow scale around head's patient. There is a history of allergies to antibiotics and postoperative anesthetics. Patient also has a repeated hospitalization for more than 5 times with the same complaint. Biopsies have been performed with the aim of determining the cause of erythroderma, preventing recurrence and proper treatment. Examination of skin biopsy results found parakeratosis cells and spongiosis cells, but no malignant cells were found.
\end{abstract}

Keyword: Erythroderma, Drug Eruption, Skin Biopsy

*DRA: Penulis korespondensi, E-mail: dr_r1n1@yahoo.com 


\section{Pendahuluan}

Eritroderma ialah kelainan kulit ditandai eritema universalis $(90 \%-100 \%)$, biasanya disertai skuama. Bila eritemanya antara 50\%-90\% disebut pre-eritroderma. Nama lain penyakit ini Dermatitis Eksfoliativa Generalisata (DEG). Eritroderma dapat timbul akibat alergi obat sistemik, perluasan penyakit kulit (psoriasis, dermatitis atopik atau dermatitis seboroik/Leiner Diseases), dan akibat penyakit sistemik termasuk keganasan atau Sezary Syndrome. ${ }^{1}$

Insiden eritroderma di Amerika Serikat bervariasi, antara 1 sampai 71 per 100.000 penderita rawat jalan dermatologi sedangkan di India melaporkan 35 per 100.000 penderita. Insidensi eritroderma di Indonesia, tepatnya di RSUD Dr. Soetomo Surabaya, jumlahnya 30 orang $(1,2 \%)$ dari seluruh penderita rawat inap. ${ }^{4}$ Sedangkan di RSUD Dr. Moewardi Surakarta, selama kurun waktu dua tahun didapatkan 485 pasien yang dirawat di Instalasi Rawat Inap Kesehatan Kulit dan Kelamin RSUD Dr. Moewardi, Solo. Tiga puluh sembilan $(8,04 \%)$ orang merupakan pasien eritroderma. Pada tahun 2012 didapatkan 12 kasus (5,6\%) dan tahun 2013 terjadi peningkatan dengan jumlah 27 kasus $(9,89 \%){ }^{5}$ Rata-rata insiden eritroderma lakilaki lebih besar daripada perempuan, dengan proporsi 2:1 sampai 4:1, dan usia rata-rata 41-61 tahun. ${ }^{6}$ Angka kematian tergantung pada penyebab eritroderma. Diagnosis eritroderma ditegakkan berdasarkan anamnesis, gambaran klinis, dan pemeriksaan laboratorium, pemeriksaan histopatologi dapat membantu menentukan penyakit yang mendasarinya. Pengobatan disesuaikan dengan penyakit yang mendasarinya, namun tetap memperhatikan keadaan umum, seperti keseimbangan cairan dan elektrolit tubuh, memperbaiki hipoalbumin, anemia, serta pengendalian infeksi sekunder.

Eritroderma bukan kasus yang sering ditemukan, namun masalah yang ditimbulkannya cukup parah dan sering kali para dokter ahli penyakit kulit dan kelamin mengalami kesulitan dalam penatalaksanaannya. Diagnosis yang ditegakkan lebih awal, cepat dan akurat serta penatalaksanaan yang tepat sangat memengaruhi prognosis penderita.

\section{Kasus}

Seorang pasien laki-laki berumur 60 tahun masuk rumah sakit dengan keluhan gatal dan muncul ruam merah pada seluruh tubuh, bercak-bercak putih di lidah, tenggorokan terasa banyak lendir, nyeri menelan sehingga asupan pasien menurun. Sekitar satu bulan yang lalu pasien dirawat inap dengan keluhan yang sama selama lima hari dan dikonsul ke dokter spesialis Telinga Hidung Tenggorokan bedah Kepala dan Leher (THT-KL) dan dirujuk ke RSUD Dr. Soetomo Surabaya untuk pemasangan Naso Gastric Tube (NGT) dengan diagnosa Achalazia. Sebeumnya pasien juga dirawat inap dengan keluhan yang sama sekitar satu bulan sebelumnya.

Lima minggu sebelumnya, pasien juga diwawat dengan keluhan gatal-gatal di seluruh tubuh sejak satu hari sebelumnya dan memberat pada pagi hari saat berobat, gatal lebih dirasakan saat pasien berkeringat. Keluhan disertai ruam eritema hampir di seluruh tubuh, kulit telapak tangan mengelupas, dijumpai sisik-sisik berwarna putih teraba kasar di bagian wajah dan berwarna kekuningan di bagian kulit kepala, luka lecet di beberapa bagian tubuh bekas garukan, dan pasien mengeluhkan mualmuntah sejak beberapa hari terakhir.

Sebelumnya pasien memiliki riwayat trauma sekitar tujuh bulan sebelum sakit sekarang. Satu bulan setelah trauma pasien masuk Rumah Sakit (RS) dengan keluhan nyeri pinggang menjalar ke paha bawah. Keluhan dirasakan hilang timbul dan kambuh saat pasien melakukan aktivitas. Setelah 
mendapat terapi dari bagian neurologi dan rutin fisioterapi. Namun setelah itu pasien sering membeli obat deksametason secara pribadi tanpa anjuran dokter. Sejak mengkonsumsi deksametason, pasien sering mengeluhkan gatal-gatal dan wajah bengkak tapi tidak pernah dibawa berobat.

Dua bulan sebelum sakit sekarang, pasien masuk RS kembali untuk rencana operasi tulang belakang dan mendapat antibiotik profilaksis cefuroxim $750 \mathrm{mg}$ saat operasi. Pasca operasi lima hari pasien pulang dan diberikan obat antibiotik cefadroxil dan analgetik asam mefenamat dari bagian orthopedi. Pasien mengeluhkan gatal-gatal setelah meminum obat, lalu antibiotik diganti oleh dokter menjadi cefixime namun setelah mengonsumsi Cefixime pasien tetap mengeluhkan keluhan yang sama. Oleh bagian kulit dan kelamin, semua obat yang di konsumsi dihentikan, termasuk antibiotik. Satu minggu sebelum berobat sekarang pasien dirawat bersama dokter penyakit dalam dengan diagnosis Drug Eruption with Eosinophilia and Systemic Symptom (DRESS).

Pada pemeriksaan lesi ditemukan macula eritematous generalisata disertai skuama tipis berwarna putih di seluruh tubuh dan kekuningan di bagian kepala pasien. Gambaran hiperpigmentasi dengan batas tidak tegas. Kulit teraba kasar dan kering. Gambaran lesi dapat dilihat pada Gambar 1.

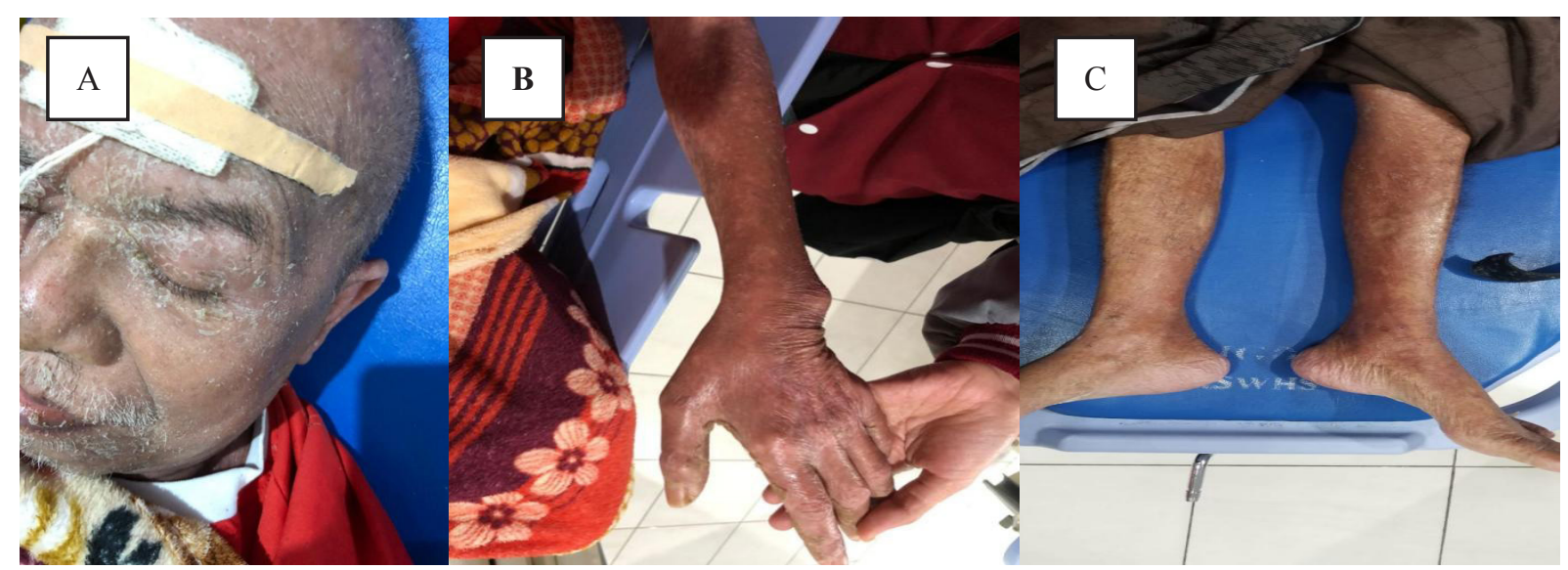

Gambar 1. A) Tampak skuama halus berwarna putih hampir diseluruh wajah pasien. B) Ruam macula eritematous generalisata disertai kulit yang kering di ekstremitas atas. C) Tampak gambaran hiperpigmentasi dengan batas tidak tegas.

Berdasarkan pemeriksaan penunjang laboratorium, pasien mengalami hipoalbunemia $(2.4 \mathrm{~g} / \mathrm{dl})$, sementara kadar hemoglobin dan lekosit normal.

Pasien mendapatkan terapi $\mathrm{NaCL}$ 0,9\% 20 tetes per menit secara intravena, injeksi metil prednisolon $3 \times 1$ ampul, injeksi difenhidramin $3 \times 1$ ampul, salep Carmed $10 \%$, vaselin album dan vipalbumin $3 \times 2$ tablet sebagai koreksi albumin pasien yang diketahui mengalami hipolabunemia.

Beberapa hari setelah perawatan, dilakukan pemeriksaan biopsi kulit, sampel diambil dari kulit regio pedis sinistra.
Sampel berupa satu potong jaringan dengan ukuran $0.8 \mathrm{~cm}$, padat abu-abu kecoklatan. Pemeriksaan mikroskopis menunjukkan potongan jaringan kulit mengalami parakeratosis, spongiosis ringan. Pada dermis dan papilla dermis tampak fokusfokus sel radang limfosit, histiosit dan beberapa netrofil dan tidak didapatkan sel ganas pada sediaan ini.

Kesimpulan hasil biopsi kulit adalah dermatitis seboroik. Pada Gambar 2 terlihat pemeriksaan mikroskopik dari sediaan biopsi kulit. 

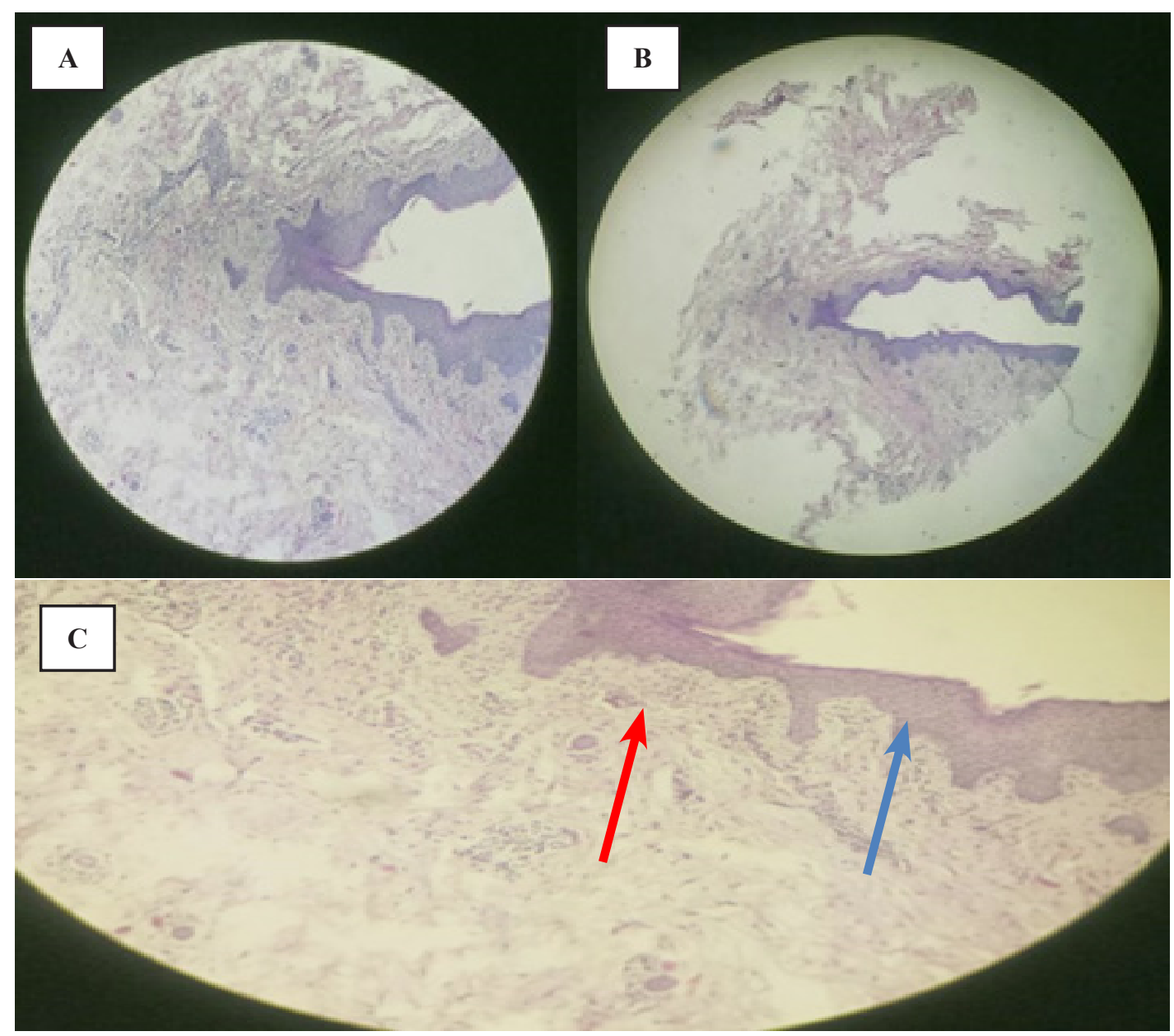

Gambar 2. Gambaran mikroskopis biopsi kulit. A) Bentuk mikroskopis jaringan kulit dengan pembesaran 10 x 0.25 B) Bentuk mikroskopis jaringan kulit dengan pembesaran 4 x 0.10 C) Tampak potongan jaringan kulit mengalami spongiosis ringan (panah merah) dan parakeratosis (panah biru). Pada dermis dan papilla dermis tampak fokus-fokus sel radang limfosit, histiosit dan beberapa neutrophil.

\section{Diskusi}

Berdasarkan teori dikatakan bahwa eritroderma et causa dermatitis seboroik yang prevalensi secara umum sekitar 3-5\% pada populasi umum dan sering dijumpai pada usia 40-60 tahun. ${ }^{6}$

Berdasarkan anamnesis, pasien mengeluhkan gatal-gatal pada seluruh tubuh, memberat saat pasien berkeringat. Pasien juga mengeluh menggigil karena pada kasus eritroderma dapat terjadi epidermal water loss, terjadinya pergantian kulit yang cepat sehingga beberapa zat tidak dimetabolisme dan diserap secara normal pada stratum korneum sehingga ditemukan skuama dan pengelupasan yang hebat. ${ }^{1}$

Dilihat dari pemeriksaan klinis, ditemukan bercak kemerahan hampir 90\% bagian tubuh, disertai sisik-sisik tipis berwana putih di sekitar kedua mata, alis dan dibagian kulit kepala dijumpai sisik tipis kekuningan, yang sering dikeluhkan gatal ketika berkeringat. Di bagian telapak tangan juga dijumpai kulit mengelupas disertai sisik-sisik berwarna putih juga. Pada dermatitis seboroik, lokasi yang terkena seringkali di daerah kulit kepala berambut yaitu alis, lipat nasolabial, telinga, liang telinga, bagian tengah-atas dada dan 
punggung serta ditandai dengan eritema universalis (90-100\%) dan skuama. ${ }^{1,7}$

Kasus dermatitis seboroik pada pasien ini dapat dibedakan dengan psoriasis yang memiliki tanda bercak-bercak eritema berbatas tegas dengan skuama kasar, berlapis-lapis dan transparan disertai fenomena tetesan lilin, Auspitz, dan Koebner. Faktor genetik juga berperan pada penyakit psoriasis, bila orang tua dari pasien tidak menderita psoriasis, maka risiko mendapat psoriasis sekitar $12 \%$, sedangkan jika salah satu orang tua menderita psoriasis, maka risiko meningkat hingga $34-39 \%{ }^{2}$

Diagnosis banding lain seperti dermatitis atopik, yang dipengaruhi cuaca dan genetik serta faktor atopi, dapat disingkirkan karena tidak terdapat faktor tersebut pada pasien.

Kadar albumin yang menurun pada eritroderma dapat beragam, menurut laporan Maharani \& Setyaningrum ${ }^{4}$, kejadian hipoalbuminemia pada pasien eritroderma bekisar 22,9\%. Menurut laporan tersebut juga disebutkan pasien dapat mengalami hipokalemia dan hiponatremia akibat dehidrasi sehingga konsentrasi elektrolit menurun serta trombositopenia. ${ }^{4}$

Berdasarkan pemeriksaan histopatologi, dermatitis seboroik akut akan memberikan gambaran spongiosis dengan infiltrat limfositik perifolikular dan perivaskular superfisial sementara dermatitis seboroik kronik memberikan gambaran akantosis iregular dan parakeratosis fokal. Sedangkan gambaran histopatologi psoriasis didapatkan akantosis ringan pada lesi awal dan hiperplasia psoriasiform pada lesi yang lama yang diakibatkan oleh migrasi netrofil dari pembuluh darah di area dermis ke epidermis, selain itu juga didapatkan mitosis keratinosit, fibroblas dan sel endotelial meningkat dan parakeratosis (inti sel didalam stratum korneum) ${ }^{2}$

Terapi yang diberikan pada kasus ini :

\section{Tabel 1. Perbedaan dermatitis seboroik, drug eruption dan psoriasis vulgaris.}

\section{Dermatitis Seboroik}

$\begin{array}{ll} & \begin{array}{l}\text { Berhubungan dengan } \\ \text { Eeningkatan aktivitas } \\ \text { kelenjar sebasea, jamur } \\ \text { Malassezia dan sistem imun. } \\ 2\end{array} \\ \text { Epidemiologi } & \begin{array}{l}\text { Prevalensi sekitar 3-5\% pada } \\ \text { populasi umum dan sering } \\ \text { dijumpai usia 40-60 tahun. }\end{array} \\ & \\ \text { Predileksi } & \begin{array}{l}\text { Daerah kulit kepala } \\ \text { berambut seperti alis, lipat } \\ \text { nasolabial, telinga, liang } \\ \text { telinga, bagian atas-tengah } \\ \text { dasa dan punggung. }\end{array} \\ & \begin{array}{l}\text { Eritema, skuama kuning } \\ \text { dan berminyak, gatal } \\ \text { menyengat. }\end{array}\end{array}$

\section{Drug Eruption}

Penggunaan obat-obatan sebelum timbul lesi berulang pada tempat yang sama. ${ }^{3}$

$10 \%$ terjadi pada anak, selebihnya dewasa. ${ }^{3}$

Lebih sering muncul di anggota gerak, mulut, mata dan genitalia. $^{3}$

\section{Psoriasis Vulgaris}

Faktor genetik berperan. ${ }^{2}$
Lesi eritematous, yang bila terjadi pemaparan obat berulang, lesi akan muncul di tempat yang sama. ${ }^{3}$
Bercak eritema batas tegas, skuama kasar dan berlapislapis disertai fenomena auspitz, tetesan lilin dan koebner. $^{2}$ 
Terapi pasien dengan eritroderma dapat beragam, tergantung dari keadaan klinis pasien, diantaranya berupa:

\section{Pemberian Cairan Infus}

Perlunya pemberian cairan pada pasien eritroderma karena sering terjadi dehidrasi akibat penguapan cairan yang meningkat. Bila suhu badan meningkat pada penderita eritroderma, kehilangan panas juga meningkat sehingga pengaturan suhu tubuh terganggu. Kehilangan panas menyebabkan hipermetabolisme kompensator dan peningkatan laju metabolisme basal. ${ }^{1}$

\section{Injeksi Kortikosteroid}

Eritroderma diduga merupakan proses sekunder dari interaksi kompleks antara molekul sitokin dan molekul adhesi selular yaitu Interleukin (IL-1, IL-2,IL-8), Tumor Necrotizing Factor (TNF) dan interferon gamma yang merupakan sitokin yang berperan dalam timbulnya eritroderma yang menyebabkan peningkatan proliferasi epidermal dan produksi mediator inflamasi. Karena inflamasi inilah sehingga diperlukan terapi kortikosteroid. ${ }^{6}$

\section{Antihistamin}

Antihistamin pada penderita eritroderma digunakan untuk mengurangi gejala pruritus. $^{1}$

\section{Krim Urea}

Krim ini bersifat emolien atau pelembab dan steroid dengan potensi rendah. Bertujuan menjaga kelembapan kulit dan mengurangi inflamasi yang terjadi. ${ }^{6}$

\section{Pemberian Albumin}

Asupan albumin dan diet tinggi protein diperlukan karena penderita eritroderma seringkali disertai hipoalbumin. Hal ini karena skuama yang terlepas mengakibatkan sel matur berada dalam epidermis relatif singkat mengakibatkan kehilangan material epidermis bersama dengan hilangnya protein dan folat. ${ }^{3}$

\section{Kesimpulan}

Diagnosis eritroderma etcausa dermatitis seboroik dapat ditegakan berdasarkan hasil anamnesis dan pemeriksaan lesi serta pemeriksaan histopatologi dari biopsi jaringan yang mengalami parakeratosis, spongiosis ringan, fokus sel radang limfosit, histiosit dan beberapa neutrophil pada dermis dan papilla dermis. Terapi disesuaikan dengan penyakit mendasarinya, namun tetap memperhatikan keadaan umum pasien, seperti keseimbangan cairan dan elektrolit tubuh, memperbaiki hipoalbumin serta pengendalian infeksi sekunder.

\section{Daftar Pustaka}

1. DjuandaA, Hamzah M, Aisah S.. Ilmu Penyakit Kulit dan Kelamin. Edisi 7. Jakarta: Fakultas Kedokteran Universitas Indonesia. 2019

2. Astindari A, Sawitri S, Sandhika W. Perbedaan dermatitis seboroik dan psoriasis vulgaris berdasarkan manifestasi klinis dan histopatologi. 2016, J e-Clinic;4(1):72-8

3. Plewig G, Jansen T. Seborrheic Dermatitis. In: Freedberg IM, Eisen AZ, Wolff K, Austen KF, Goldsmith LA, Katz S, editors. Fitzpatrick's Dermatology In General Medicine. 8th ed. New York: McGraw-Hill; 2017.

4. Maharani S, Setyaningrum T. Profil Pasien Eritroderma. Periodic Dermatol Venereol;2017.29(1):44-51

5. Mochtar M, Toha SS, Maharani SC, Trisnarizki L. Angka Kejadian Eritroderma di RSUD Dr. Moewardi Surakarta. Diunduh dari http:// www.perdoski.or.id/doc/mdvi/fulltext/30/192/ 1 Agustus 2020.

6. Widaty S, Soebono H, Nilasari H, Listiawan Y, Siswati AS, Triwahyudi D, et al. Panduan Praktik Klinis Bagi Dokter Spesialis Kulit dan Kelamin di Indonesia. Jakarta:PERDOSKI;2017.15-8.

7. Tjut N. Pilihan Pengobatan Jangka Panjang pada Dermatitis Seboroik. 2019. Jakarta:Balai FKUI 